\title{
Selection of Candidate Plus Trees (CPTs) of Malabar Neem (Melia dubia Cav.) for Enhancement of Farm Productivity in South Gujarat, India
}

\author{
R.S. Chauhan ${ }^{1 *}$, D.B. Jadeja ${ }^{2}$, N.S. Thakur ${ }^{2}$, S.K. Jha ${ }^{1}$ and M.S. Sankanur ${ }^{1}$ \\ ${ }^{1}$ Department of Forest Biology and Tree Improvement, College of Forestry, Navsari \\ Agricultural University, Navsari, Gujarat-396450, India \\ ${ }^{2}$ Department of Silviculture \& Agroforstry, College of Forestry, Navsari Agricultural \\ University, Navsari, Gujarat-396450, India \\ *Corresponding author
}

\section{A B S T R A C T}

\begin{tabular}{|l|}
\hline K e y w o r d s \\
$\begin{array}{l}\text { Melia dubia, Candidate } \\
\text { Plus Tree, Quality } \\
\text { planting material, } \\
\text { Independent culling, } \\
\text { South Gujarat }\end{array}$ \\
\hline Article Info \\
\hline $\begin{array}{l}\text { Accepted: } \\
\text { 26 April } 2018 \\
\text { Available Online: } \\
\text { 10 May } 2018\end{array}$ \\
\hline
\end{tabular}

\section{Introduction}

Tremendous pressure of the ever increasing population and impact of economic growth has put the burden on the forest resources for various end uses. The current supply of raw material for industries like pulpwood and matchwood in the country is lagging behind the demand. India's total timber wood production was estimated to be about 70.9 million $\mathrm{m}^{3}$ whereas, the total estimated wood consumption (excluding fuelwood) in India comes to about 68.9 million $\mathrm{m}^{3}$ per year. India's demand for industrial wood has been growing steadily by an average of 0.9 million $\mathrm{m}^{3}$, reflected evidently in the increase in imports of industrial round wood, which grew from 2.55 million $\mathrm{m}^{3}$ in 2001 to 6.23 million $\mathrm{m}^{3}$ in 2014. If the imports increase at the same rate for the next 15 years, India's imports in 2020, 2025 and 2030 are projected to be $22.51,27.01$ and 31.5 million $\mathrm{m}^{3}$, respectively which would create a negative impact on the economy of nation (Shrivastava and Saxena, 2017). On the other hand, contribution of forests including Forest Development Corporations (FDC) to the total domestic wood supply in the country is only 6.4 percent 
of the total domestic requirement (Aggrawal and Saxena, 2017). Hence, inadequate raw material availability from the forests forced the wood based industries to look towards the agroforestry farms for their sustenance. Since the expansion of farms areas in country is not possible due to limiting factor of land resources, enhancing the efficiency by the way of incorporating fast growing tree species on farmlands is realistic approach to satisfy the demand of wood. Presently, exotic species like Eucalyptus, Casuarina, Leucenea and Poplulus species are dominating in the agroforestry farms as major sources of raw material for pulp and plywood industries. However, these crops are constrained by numerous problems and posing threat to ecosystem. Narrow genetic base of poplar, susceptibility to blight (Wani and Malik, 2014) and multiple insect injuries (Mukhtar and Faisal, 2012) are the common causes for declined growth rate in Punjab, Haryana and Uttar Pradesh. The after-effects of Eucalyptus trees on crop production, under-storey plant diversity and soil nutrients have been reported (Kaur et al., 2007). Vulnerability to pests and diseases ((Mohanan and Sharma, 1993) and suppression of ground vegetation (Batish et al., 2001) in Casuarina are major setback in the wet tropics. Ecological concerns of Leucenea in terms of its invasiveness, threat to native species and habitat degradation are well known (Ghate, 1991; Kohli et al., 2012).

Looking to the downsides of exotic industrial plantations, there is a need to diversify our forest plantations by increasing the number of suitable indigenous fast growing trees species adaptive to wide agro climatic condition of India (Parthiban et al., 2009). Melia dubia could be one such alternate indigenous fast growing multipurpose tree species highly suitable to agroforestry systems in India with immense potential to serve the mankind by wide range of products and environmental services. The species has been reported to have transient or null allelopathic effect on understorey crops (Thakur et al., 2017a \& b; Kumar et al., 2017; Parmar et al., 2018) hence could be a promising agroforestry ideotype.

Melia dubia belongs to family Meliaceae, is an economically important tree species known as Malabar Neem. It is a majestic deciduous tree indigenous to India, South East Asia and Australia growing to a height of $30 \mathrm{~m}$ with the spreading crown and clear bole of $9 \mathrm{~m}$. It occurs in tropical moist deciduous forests of the Sikkim Himalayas, North Bengal and upper Assam, Khasi hills, hills of Orissa, Deccan and the Western Ghats. It grows up to an altitude of 1,500-1,800 meters (Troup, 1921). Wood of M. dubia is an excellent and highly suitable raw material for wood based industries like paper and plywood industries owing to its natural anti-termite property, high pulp recovery and exceptional fibre strength as compared to traditional raw material (Sarvannnan et al., 2013). Recent studies have revealed its therapeutic properties, which reveal that almost all parts of the tree are medicinally important. Fruits are having antihelminthic property and used to treat colic. The fruit extracts of the plant found to be an effective hypo-glycaemic agent and antioxidant useful in treating diabetes (Velentina et al., 2013). The leaf is a good source of essential oil camphene, and exhibited bacterostatic and fungistatic activities against wide range of human pathogens (Malarvannan et al., 2009). The leaf and bark extract has anti-feedant (Koul et al., 2000), insecticidal, anti-larval property (Yasodha et al., 2012). Recently fruit and leaf extracts have shown anti-inflammatory, anticancer and hepato-protective activities (Gopal et al., 2015). Matured Leaves of Melia dubia are rich source of mineral elements, crude protein, crude lipid and vitamins and make excellent fodder for ruminates (Leela et al., 2016). Beside the economical utilities, environmental services are also offered by $M$. dubia. It is grown as shade tree in coffee and tea plantations. M. dubia along with 
Trichoderma viridae has the capacity to degrade commonly occurring pesticide in soil (Subasini et al., 2010).

Selection of the best seed source of any species for a given region is essential to enhance the productivity of agroforestry systems (Tak and Jindal, 2014). Hence the first step and challenging task is the screening of naturally available population to select and propagate the best planting material for higher productivity. Despite the huge importance, multifarious uses, vast distribution range of $M$. dubia in India and significant genetic variation, hitherto very limited efforts have been made to exploit maximum genetic gain for enhancing productivity of farmlands. Present study is undertaken to realize the genetic variation for the development of quality planting material.

\section{Materials and Methods}

\section{Selection area}

In the present study, 20 candidate plus trees of $M$. dubia showing good phenotype have been selected from different places covering three districts of South Gujarat region viz., Valsad, Narmada and The Dangs. The climate of south Gujarat region, from where selection was made, is typically tropical, characterized by fairly hot summer, moderately cold winter and humid and warm monsoon. Most of the precipitation is received from south west monsoon, concentrated during the month of June, July and August. Individual tree location, geographic information along with geo co-ordinates was recorded using Global Positioning System (Make \& Model: e-Trax vista, Garmin) (Table 1).

\section{Selection procedure}

Different localities, where the Melia dubia found to grown naturally viz. Dharampur, Kaprada, Dabkhal, Wagahi, Dediyapada,
Sagai and Sagbara falling in three districts of south Gujarat region were extensively surveyed to identify the CPTs of selected tree species. Selection was made from sparse population of Melia dubia growing naturally around the habitat, farm boundaries and forest area that were average or better in traits of interest. Out of the trees visited, twenty CPTs were selected with age more than half of the rotation age of the species. Individual tree selection approach with independent culling method suggested by Surendran et al., (2003) were followed for the selection of superior phenotype. Candidates qualifying minimum selection standards were selected and marked with yellow band with the number. In case, many trees available nearby for comparison, judgment was taken to select the trees having high phenotypic value. The CPTs were not selected too close to each other in order to avoid narrowing down of the genetic base due to relatedness or inbreeding (Turnbull, 1975). Aerial distance of at least one kilometre between individuals was maintained (Fig. 1).

The selection criteria for CPTs vary from species to species but many of the basic characteristics are quite considerable. The objective was that the selected individual should have good stem form, good growth characters, well-formed crown, natural pruning ability and free from pests and diseases. The individuals having diseases, dead branches, or attacked by any pathogen and pests were rejected in the initial stage of selection. Major economic characteristics considered for the CPT selection were the stem straightness, cylindrical clear bole, Girth at breast Height $(\mathrm{GBH})$, tree height and branch angle. Tree with average or better traits of interest were preliminary screened on the basis of bole straightness and roundness by assigning visual scores. No tree was selected having the clear bole height below $5 \mathrm{~m}$ and GBH $100 \mathrm{~cm}$ despite of superiority in other traits. No tree was accepted with forking or excess crookedness up to 5 meter from the 
ground. Tree height was recorded by using Ravi altimeter from base of tree to tip of the tree. Girth at Brest Height (GBH) was measured at $1.37 \mathrm{~m}$ height from the base of tree using standard measuring tape and expressed in nearest centimetre. Clear bole height was recorded with Ravi altimeter from tree base to the first live branch on the main stem and expressed in meter. Trees were not accepted with branch angle more than $90^{\circ}$. Degree of branch angle was judged subjectively by considering upper stem portion as base. Ability of candidate tree to shed its lower limbs (dead or alive) as compared to other tree was also judged subjectively. The data recorded were subjected simple statistical analysis using excel work book.

\section{Results and Discussion}

The analysis of variance revealed significant variation among twenty selected CPTs in the present study (Table: 2; Plate 2). Among all selected plus trees, girth at breast height $(\mathrm{GBH})$ ranged from 101.80 to $170.20 \mathrm{~cm}$. The highest GBH (170.2) was observed in NAU20 whereas the lowest value recorded in NAU-12 $(101.80 \mathrm{~cm})$. Among all selected plus trees, six CPTs were within the range of 151$175 \mathrm{~cm}$ girth class, however seven trees each were found within the girth class 126.00$150.00 \mathrm{~cm}$ and $100.00-125.00 \mathrm{~cm}$. In the present study range of clear bole height $(\mathrm{CBH})$ varied between 5.10-10.80 m. Maximum CBH was observed for NAU- $13(10.80 \mathrm{~m})$ while, minimum was recorded in NAU-19 $(5.10 \mathrm{~m})$. Range class distribution suggested that nine CPTs fall in the $5.00-7.00 \mathrm{~m}$, seven in 7.10$9.00 \mathrm{~m}$ and rest four CPTs in $9.10-11.00 \mathrm{~m}$ $\mathrm{CBH}$ class. Tree height, from ground to tip, of the selected CPTs ranged from 14.20 to 26.20 $\mathrm{m}$. NAU-11 was found to be tallest $(26.20 \mathrm{~m})$ whereas; shortest $(14.20 \mathrm{~m})$ was of NAU-10. $\mathrm{CBH}$ : $\mathrm{TH}$ ratio found to be varied from 0.25 to 0.61. Maximum $\mathrm{CBH}$ : $\mathrm{TH}$ ratio was recorded in NAU-5 whereas, minimum $\mathrm{CBH}$ : $\mathrm{TH}$ ratio was recorded in NAU-3. Out of the selected CPTs, one fell in the range of 0.56-0.65 class, two in $0.46-0.55$, seven in $0.36-0.45$ and ten occupied the place in $0.25-0.35$ class. Moreover, visual scores (on the scale of 1-5) for quantitative traits like stem straightness and roundness were found to vary from 3-5 in all the selected CPTs (Fig. 2).

Selection of good phenotype on the basis of desired traits is the preliminary steps for mass scale multiplication programme and genetic improvement of any tree species (Clark and Wilson, 2005). Determination of the best selection techniques depends on several factors including species characters, stand characteristics, past history, variability and inheritance pattern of important characteristics and objectives of the selection programme. Since the selection of candidate plus tree is made from existing uneven aged population of M. dubia growing in scattered form in the forest area of south Gujarat, Individual tree selection approach were followed as prescribed by Ledig, 1974. This method of selection proved to be most used and generally the most satisfactory to make genetic gain quickly and inexpensively in a beginning tree improvement programme (Zobel and Talbert, 1984). Furthermore, in the present study, phenotypically superior individuals were selected through independent culling method (Surendran et al., 2003). Owing to nonavailability of volume tables to make growthage correlation, a predetermined scale for the minimum acceptable standards were fixed for qualitative as well as quantitative traits.

Selection traits may differ largely depending upon the end use of the species in question. However, in order to make the selection efficient, Hazel and Lush (1942) emphasized on consideration of the 1) extent of genetic variation present in the population (relative economic value of trait), 2) heritability of the traits and 3) genetic and environmental correlation of each trait with the other. 
Table.1 Details of tree location along with geo-coordinates and biometric information of 20 selected M. dubia Candidate Plus Trees (CPTs)

\begin{tabular}{|c|c|c|c|c|c|}
\hline \multirow{2}{*}{$\begin{array}{c}\text { Tree Code (Accession } \\
\text { Number) }\end{array}$} & \multicolumn{2}{|c|}{ GPS co-ordinates } & \multirow{2}{*}{$\begin{array}{l}\text { Altitude } \\
\text { (m) }\end{array}$} & \multirow[t]{2}{*}{ Place } & \multirow[t]{2}{*}{ District } \\
\hline & Latitude & Longitude & & & \\
\hline NAU-01 & $20^{\circ} 29^{\prime} 25^{\prime \prime} \mathrm{N}$ & $73^{\circ} 09^{\prime} 31^{\prime \prime} \mathrm{E}$ & 87 & Dharampur & Valsad \\
\hline NAU-02 & $20^{\circ} 26^{\prime} 04^{\prime \prime} \mathrm{N}$ & $73^{\circ} 08^{\prime} 58^{\prime \prime} \mathrm{E}$ & 63 & Nanapondha & Valsad \\
\hline NAU-03 & $20^{\circ} 24^{\prime} 49^{\prime \prime} \mathrm{N}$ & $73^{\circ} 09^{\prime} 03^{\prime \prime} \mathrm{E}$ & 68 & Nanapondha & Valsad \\
\hline NAU-04 & $20^{\circ} 23^{\prime} 33^{\prime \prime} \mathrm{N}$ & $73^{\circ} 08^{\prime} 52^{\prime \prime} \mathrm{E}$ & 70 & Nanapondha & Valsad \\
\hline NAU-05 & $20^{\circ} 24^{\prime} 17^{\prime \prime} \mathrm{N}$ & $73^{\circ} 08^{\prime} 38^{\prime \prime} \mathrm{E}$ & 73 & Nanapondha & Valsad \\
\hline NAU-06 & $20^{\circ} 22^{\prime} 29^{\prime \prime} \mathrm{N}$ & $73^{\circ} 09^{\prime} 48^{\prime \prime} \mathrm{E}$ & 129 & Kaprada & Valsad \\
\hline NAU-07 & $20^{\circ} 21^{\prime} 41^{\prime \prime} \mathrm{N}$ & $73^{\circ} 11^{\prime} 22^{\prime \prime} \mathrm{E}$ & 112 & Kaprada & Valsad \\
\hline NAU-08 & $20^{\circ} 19^{\prime} 92^{\prime \prime} \mathrm{N}$ & $73^{\circ} 16^{\prime} 65^{\prime \prime} \mathrm{E}$ & 467 & Dabkhal & Valsad \\
\hline NAU-09 & $20^{\circ} 18^{\prime} 43^{\prime \prime} \mathrm{N}$ & $73^{\circ} 19^{\prime} 02^{\prime \prime} \mathrm{E}$ & 424 & Dabkhal & Valsad \\
\hline NAU-10 & $20^{\circ} 20^{\prime} 23^{\prime \prime} \mathrm{N}$ & $73^{\circ} 15^{\prime} 22^{\prime \prime} \mathrm{E}$ & 387 & Dabkhal & Valsad \\
\hline NAU-11 & $20^{\circ} 45^{\prime} 47^{\prime \prime} \mathrm{N}$ & $73^{\circ} 29^{\prime} 9^{\prime \prime} \mathrm{E}$ & 144 & Waghai & The Dangs \\
\hline NAU-12 & $20^{\circ} 46^{\prime} 25^{\prime \prime} \mathrm{N}$ & $73^{\circ} 30^{\prime} 23^{\prime \prime} \mathrm{E}$ & 127 & Waghai & The Dangs \\
\hline NAU-13 & $20^{\circ} 48^{\prime} 42^{\prime \prime} \mathrm{N}$ & $73^{\circ} 29^{\prime} 55^{\prime \prime} \mathrm{E}$ & 132 & Waghai & The Dangs \\
\hline NAU-14 & $20^{\circ} 45^{\prime} 5^{\prime \prime} \mathrm{N}$ & $73^{\circ} 29^{\prime} 56^{\prime \prime} \mathrm{E}$ & 150 & Waghai & The Dangs \\
\hline NAU-15 & $20^{\circ} 47^{\prime} 33^{\prime \prime} \mathrm{N}$ & $73^{\circ} 31^{\prime} 14^{\prime \prime} \mathrm{E}$ & 128 & Waghai & The Dangs \\
\hline NAU-16 & $21^{\circ} 42^{\prime} 16^{\prime \prime} \mathrm{N}$ & $73^{\circ} 48^{\prime} 8^{\prime \prime} \mathrm{E}$ & 340 & Sagai & Narmada \\
\hline NAU-17 & $20^{\circ} 41^{\prime} 17^{\prime \prime} \mathrm{N}$ & $73^{\circ} 47^{\prime} 31^{\prime \prime} \mathrm{E}$ & 385 & Sagai & Narmada \\
\hline NAU-18 & $21^{\circ} 36^{\prime} 19^{\prime \prime} \mathrm{N}$ & $73^{\circ} 45^{\prime} 19^{\prime \prime} \mathrm{E}$ & 405 & Sagai & Narmada \\
\hline NAU-19 & $21^{\circ} 36^{\prime} 23^{\prime \prime} \mathrm{N}$ & $73^{\circ} 44^{\prime} 50^{\prime \prime} \mathrm{E}$ & 53 & Sagbara & Narmada \\
\hline NAU-20 & $20^{\circ} 45^{\prime} 5^{\prime \prime} \mathrm{N}$ & $73^{\circ} 29^{\prime} 56^{\prime \prime} \mathrm{E}$ & 394 & Sagbara & Narmada \\
\hline
\end{tabular}


Table.2 Quantitative and qualitative growth characters of selected 20 CPTs of M. dubia

\begin{tabular}{|c|c|c|c|c|c|c|}
\hline CPT No. & $\begin{array}{l}\text { Girth at breast height } \\
\text { (GBH in } \mathrm{cm})\end{array}$ & $\begin{array}{l}\text { Clear bole height } \\
\text { (CBH in } \mathrm{m})\end{array}$ & $\begin{array}{l}\text { Tree height } \\
\text { (TH in } \mathbf{m} \text { ) }\end{array}$ & $\begin{array}{c}\text { CBH:TH } \\
\text { (m) }\end{array}$ & $\begin{array}{c}\text { Straightness } \\
\text { (Visual score) 1-5 }\end{array}$ & $\begin{array}{c}\text { Roundness } \\
\text { (Visual score) 1-5 }\end{array}$ \\
\hline NAU- 01 & 108.20 & 7.75 & 15.30 & 0.51 & 4 & 3 \\
\hline NAU- 02 & 129.10 & 5.50 & 17.50 & 0.31 & 3 & 3 \\
\hline NAU -03 & 151.40 & 5.20 & 20.70 & 0.25 & 3 & 4 \\
\hline NAU -04 & 141.10 & 6.80 & 18.50 & 0.37 & 4 & 4 \\
\hline NAU-05 & 148.60 & 10.10 & 16.50 & 0.61 & 4 & 4 \\
\hline NAU- 06 & 132.20 & 7.40 & 20.10 & 0.37 & 3 & 4 \\
\hline NAU -07 & 131.30 & 8.40 & 25.60 & 0.33 & 5 & 4 \\
\hline NAU -08 & 120.70 & 6.60 & 18.20 & 0.36 & 4 & 3 \\
\hline NAU- 09 & 136.30 & 5.60 & 18.50 & 0.30 & 4 & 3 \\
\hline NAU- 10 & 104.20 & 5.80 & 14.20 & 0.41 & 4 & 4 \\
\hline NAU -11 & 165.10 & 8.10 & 26.20 & 0.31 & 3 & 3 \\
\hline NAU -12 & 101.80 & 6.80 & 18.80 & 0.36 & 4 & 4 \\
\hline NAU -13 & 106.70 & 10.80 & 20.00 & 0.54 & 4 & 4 \\
\hline NAU -14 & 156.20 & 7.50 & 22.20 & 0.34 & 4 & 3 \\
\hline NAU -15 & 155.10 & 10.50 & 25.40 & 0.41 & 5 & 4 \\
\hline NAU -16 & 105.30 & 10.10 & 24.20 & 0.42 & 4 & 4 \\
\hline NAU- 17 & 166.10 & 7.10 & 24.80 & 0.29 & 4 & 4 \\
\hline NAU -18 & 129.60 & 7.40 & 26.10 & 0.28 & 4 & 4 \\
\hline NAU -19 & 103.90 & 5.10 & 20.00 & 0.26 & 4 & 4 \\
\hline NAU- 20 & 170.20 & 5.30 & 17.20 & 0.31 & 4 & 4 \\
\hline Min. & 101.8 & 5.10 & 14.2 & 0.25 & 3 & 3 \\
\hline Max. & 170.2 & 10.8 & 26.2 & 0.61 & 5 & 4 \\
\hline Mean & 133.15 & 7.39 & 20.5 & 0.367 & 3.9 & 3.7 \\
\hline $\mathrm{SE} \pm$ & 5.16 & 0.41 & 0.84 & 0.02 & 0.12 & 0.11 \\
\hline CV\% & 17.31 & 24.59 & 18.34 & 25.85 & 14.17 & 12.71 \\
\hline
\end{tabular}

Table.3 Correlation matrix of growth characters of selected CPTs of Melia dubia

\begin{tabular}{|l|l|l|l|}
\hline Character & \multicolumn{1}{|c|}{ GBH } & \multicolumn{1}{c|}{ CBH } & \\
\hline GBH & 1.000 & & \\
\hline CBH & $-0.033^{\mathrm{NS}}$ & 1.000 & 1.000 \\
\hline TH & $0.488^{* *}$ & $0.384^{* *}$ & 1.00 \\
\hline
\end{tabular}

Note: $\mathrm{GBH}=$ Girth at Breast Height, $\mathrm{CBH}=$ Clear Bole Height, $\mathrm{TH}=$ Tree Height

**Significant at $0.1 \%$ probability level 

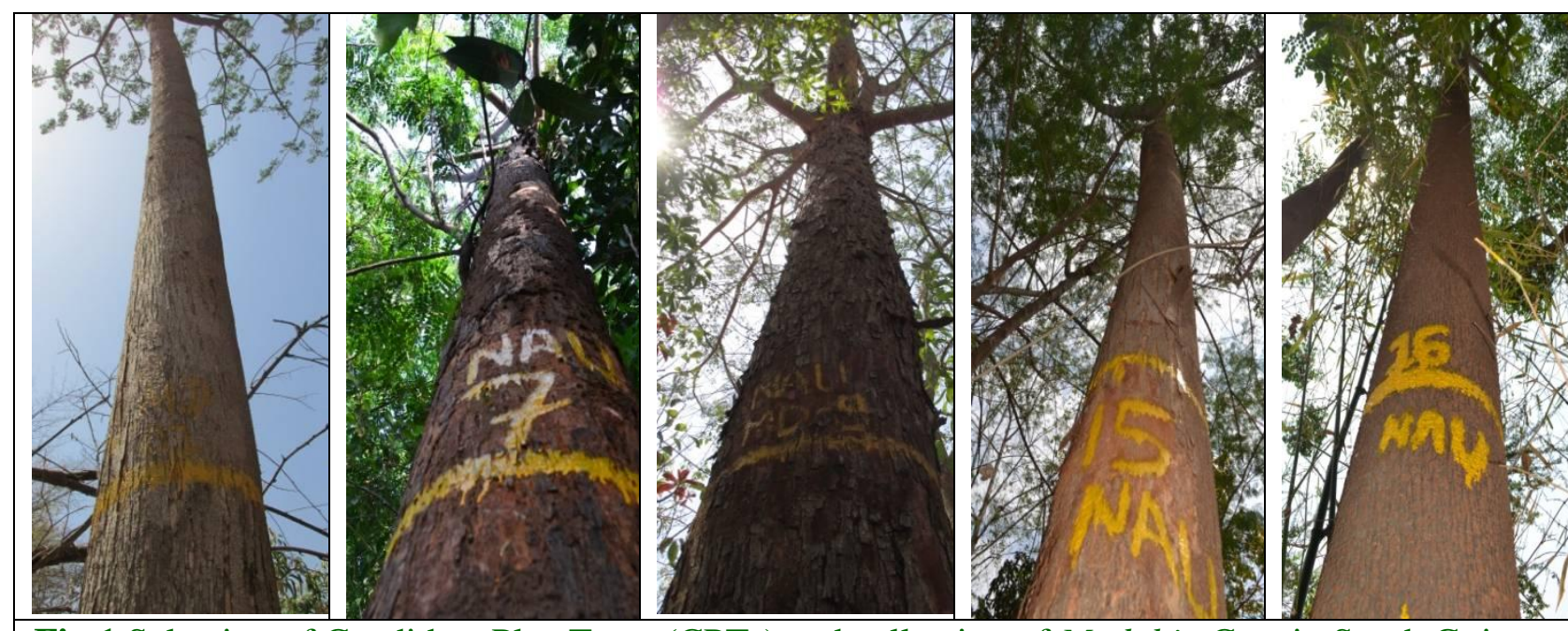

Fig.1 Selection of Candidate Plus Trees (CPTs) and collection of $M$. dubia Cav. in South Gujarat

Fig.2 Range class distribution of growth characters of selected CPTs of Melia dubia
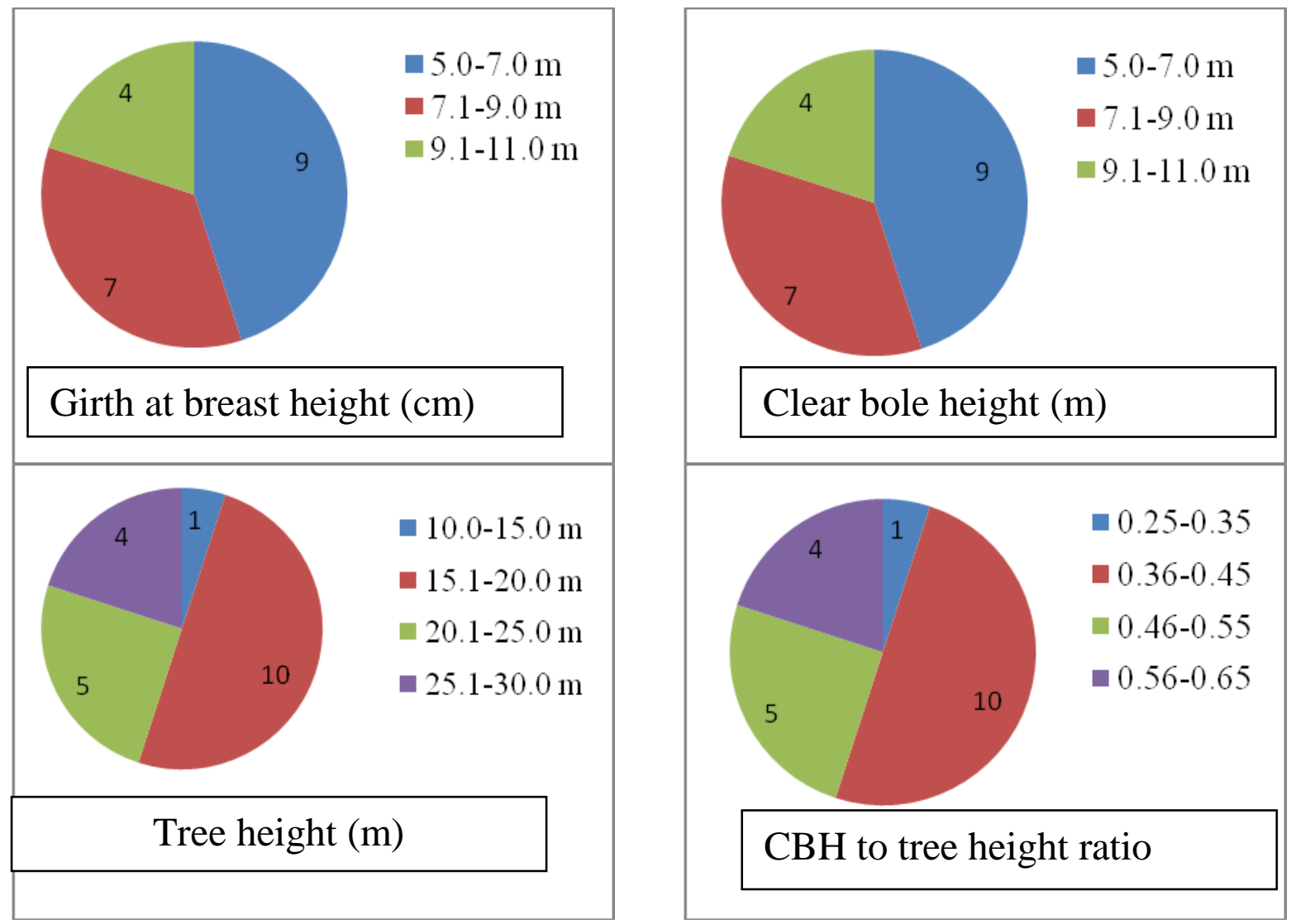

Note: Number of selected CPTs falling the range class in circle

Below, attempts are being made to discuss the efficiency of selection in the present study based on these considerations.
In the present study, 20 candidate plus trees of M. dubia were selected from natural population covering three geographical 
regions of South Gujarat. Considerable variability in terms of growth characters like tree height, girth and clear bole height was observed in the scattered population, reflected evidently in the growth data of selected trees (Table 2). Second important consideration while deciding the selection criteria, as suggested by Hazel and Lush (1942) is the heritability of those selection traits. Stem straightness and roundness is known to have direct relationship with wood quality and easy handling in processing even simple selection of tree form can improve the quality and quantity of product (Shelbourne, 1969; Zobel and Talbert, 1984) hence, selection of CPTs was done preliminary based on stem form. Estimation of heritability and additive genetic coefficient of variation for parental growth and stem form traits over offspring were studied earlier by many workers. Cornelius (1994) reviewed the heritability of seven traits of forest trees and the heritability of form traits (straightness and roundness) were found higher than the growth traits. The analysis of additive genetic coefficients of variation suggested that height and diameter (medians 8.5 and $8.6 \%$, respectively) had lower values than straightness (median 11.65\%). Since, $M$. dubia is widely promoted as potential pulpwood and plywood species therefore, economic traits like girth size, clear merchantable bole height, tree height and clear bole height : tree height ratio were also given priority for individual tree selection. High heritability accompanied by high genetic advance for several growth characteristics have also been demonstrated in growth characters like tree height, diameter (Ferguson et al., 1977; Naraynan et al., 2009; Dlamini et al., 2017), clear bole height (Jha, 2013) and bole straightness (Vargas-Reeve et al., 2013). Therefore, inclusion of these traits as selection criteria, confirms the reliability of selection of superior phenotype under the present study. Similar, growth characters were used for selection of candidate plus trees by many scientists. Johar et al., (2016) selected 24 candidates plus tree of $M$. composita on the basis of stem straightness; clear bole height, pruning ability and disease resistance. Similarly, Kumar et al., (2013) selected the 20 plus trees of $M$. dubia in Tamil Nadu based on growth attributes viz. basal diameter, plant height and volume index. Chauhan and Gera (2012) also selected 11 CPTs of $M$. composita in Punjab by considering economic traits like tree height, GBH, straightness, selfpruning ability and crown spread. Kumar et al., (2013) selected 58 most divergent plus trees of $M$. composita from Uttarakhand based on height, collar diameter, diameter at breast height; clear bole height, straightness and incidence of pests and diseases. Interestingly, Kariuki et al., (2016) selected 100 CPTs of $M$. volkensii in Kenya on the basis of height and diameter growth, stem straightness and branching pattern. Third consideration for the selection of candidate plus tree, as suggested by Hazel and Lush, (1942) is the genetic and environmental correlation between selection traits. Stem girth at breast height and tree height are commonly recorded measures that gave an idea about the tree growth. In the present investigation, tree growth characters found to be significantly correlated with each other. Tree height was significantly correlated with $\mathrm{GBH}$ as well as $\mathrm{CBH}$ at $1 \%$ probability level. Girth at breast height $(\mathrm{GBH})$ recorded significantly positive correlation with the tree height but, recorded non-significant negative relation with the clear bole height $(\mathrm{CBH})$ (Table 3). Similar observations were made by Tewari et al., (2012) in Prosopis juliflora and Gupta et al., (2012) in Acacia catechu. Present findings suggest that tree with larger height had larger girth at breast height so direct selection on the basis of these characters may enhance the genetic gain in subsequent progeny. In the study, there was no significant relationship of $\mathrm{GBH}$ and $\mathrm{CBH}$ was found and might be due to natural pruning ability of a particular tree hence this 
character should be considered separately for the selection of candidate plus trees. Furthermore, Johar et al., (2016) and Chauhan and Gera (2012) have considered natural pruning ability trait while selection of CPTs in M. composita.

\section{Acknowledgement}

Authors are highly thankful to the Directorate of Research and PG studies, Navsari Agricultural University, Navsari, Gujarat for providing the necessary facilities and funds for conducting the study.

\section{References}

Agarwal, S. and Saxena, A. K. (2017). The Puzzle of forest productivity: are forest development corporations solving it right? Centre for science and environment, New Delhi. (http:// www.indiaenvironmentportal.org.in/file s/file/the-puzzle-of-forest-productivityreport.pdf).

Batish, D. R., Singh, H. P., and Kohli, R. K. 2001. Vegetation exclusion under Casuarina equisetifolia L.: does allelopathy play a role? Community Ecology. 2: 93-100.

Chauhan, S., and Gera, M. 2012. Selection of candidate plus trees of commercially important agroforestry species in Punjab. Indian Journal of Forestry. 35: 135-142.

Clark, J., and Wilson, T. 2005. The importance of plus-tree selection in the improvement of hardwoods. Quarterly Journal of Forestry. 99(1): 45-50.

Cornelius, J. 1994. Heritabilities and additive genetic coefficients of variation in forest trees. Canadian Journal of Forest Research. 24(2): 372-379.

Dlamini, L. N., Pipatwattanakul, D., and Maelim, S. 2017. Growth variation and heritability in a second-generation
Eucalyptus urophylla progeny test at Lad Krating Plantation, Chachoengsao province, Thailand. Agriculture and Natural Resource. 51: 158-162.

Ferguson, R. B., Land, J. R., and Cooper, D. T. 1977. Inheritance of growth and crown characters in American sycamore. Silvae Genetica. 26: 5-6.

Ghate, V. S., (1991). Noteworthy plant invasions in the flora of Western Ghats of Maharashtra. Journal of the Bombay Natural History Society. 88(3): 390394.

Gupta, T., Tej, P., and Gupta, R. K. 2012. Genetic variability and correlation study in Acacia catechu seed source in Himachal Pradesh. Range Management and Agroforestry. 33 (1): 47-52.

Hazel, L. N., and Lush, J. L. 1942. The efficiency of three methods of selection. Journal of Heredity. 33: 393399.

Jha, R. K., 2012. A study of variability, associations, and path analysis in poplar (Populus deltoides Bartr. ex Marsh). Journal of Sustainable Forestry. 31(3): 185-204.

Johar, V., Bhambani, K., Sharma, R., and Kumar, P. 2016. Plus tree selection and progeny testing of Burma Dek (Melia composita Willd.). Indian Journal Ecology. 43(1): 364-367.

Kariuki, J., Hanaoka, S., Miyashita, B., and Muchiri, D. 2016. Breeding for improved Melia seed and seedlings. In: guideline on production, distribution and use of improved melia seed and seedlings in the drylands of Kenya. Kamondo, B. M., Kariuki, J. G., Luvanda, A. M., Muturi, G. M., and Ochieng, D. (Eds.), KEFRI Publication, Kenya. Pp-8.

Kaur, K., Jalota, R. K., and Kohli, R. K. 2007. Social acceptance for ecological services of exotic Eucalyptus tereticornis and indigenous Dalbergia 
sissoo plantations in $\mathrm{N}-\mathrm{W}$ India. International Journal of Ecological Economics \& Statistics Winter. 7(7): 68-85.

Kohli, R. K., Batish, D. R., Singh, J. S., Singh, H. P., and Bhatt, J. R. 2012. Plant invasion in India: An overview in invasive alien plants. In: An ecological appraisal for Indian subcontinent. Bhatt, J.R., et al., (Ed.) CABI International electronic book. pp 1-10.

Koul, O., Jain, M. P., and Sharma, V. K. 2000. Growth inhibitory and anti feedant activity of extracts from Melia dubia cav to Spodotera litura and Helicoverpa armigera larvae. Indian Journal of Experimental Biology. 38(1): 63-68.

Kumar, A. P., Dobhal, S., Sharma, S., Ahmed, N., and Rawat, U. S. 2013. Genetic screening and improvement of Melia composita Willd. Annals of Forestry. 21(2): 189-196.

Kumar, P., Parthiban, K. T., and Saravanan, V. 2013. Genetic variations among open pollinated families of selected better trees in Melia dubia. Research. Journal of Recent Science. 2:189-194.

Ledig, T. F., 1974. An analysis of methods for the selection of trees from wild stands. Forest Science. 20: 2-16.

Leela, G., Dayana, J., Monisha, S., Irudaya, I., Anitha, A., and Rosaline, J.V. 2016. Studies on phytochemical, nutritional analysis and screening of in vitro biological activities of Melia dubia leaf extract. International Journal of Scientific \& Engineering Research. 7(8): 56-68.

Malarvannan, S., Giridharan, R., Sekar, S., Prabavathy, V. R., and Sudha, N. 2009. Ovicidal activity of crude extracts of few traditional plants against Helicoverpa armigera (Hubner) (Noctuidae: Lepidoptera). Journal of Biopesticides. 2(1): 64-71.
Mohanan, C., and Sharma, J.K. 1993. Diseases of Casuarina equisetifolia in India. The Commonwealth Forestry Review.72 (1):48-52.

Mukhtar, A., and Mohammad, F. 2012. Status of insect pests of poplar in India with special reference to Clostera spp. Forestry Bulletin. 12(1): 105-122.

Naraynan, C., Chawhaan, P.H., and Mandal, A.K. 2009. Inheritance Pattern of Growth and Wood Traits in Teak (Tectona grandis L.f.). Silvae Genetica. 58 (3): 97-101.

Panse, V. G., and Sukhatme, P. V. 1967. Statistical methods for agricultural workers. ICAR, New Delhi-6.

Parthiban, K. T., Akilesh, K. B., Seenivasan, R., Kamala, K., and Govinda, R. M. 2009. Integrating Melia dubia in agroforestry farms as an alternate pulpwood species. Asia Pacific Agroforstry News Letter No.34, Thammada Press Co. Ltd., Bangkok, Thailand. Pp. 3-4.

Saravanan, V., Parthiban, K. T., Kumar, P., and Marimuthu, P. 2013. Wood characterization studies on Melia dubia Cav. for pulp and paper industry at different age gradation. Research Journal of Recent Sciences. 2(ISC2012): 183-188.

Shelbourne, C. J. A., 1969. Breeding for stem straightness in conifers. Doc. Second World Cons. Forest Tree Breed. 1: 293 302.

Shrivastava, S., and Saxena, A. K. 2017. Wood is Good: But, is India doing enough to meet its present and future needs? Centre for Science and Environment, New Delhi. (http://www. cseindia.org/userfiles/wood-is-good.pdf ).

Subasini, H. D., Sekar, S., Shri, L., and Devi, V. R. 2007. Biodegradation of pesticidal rsidue using traditional plants with medicinal properties and Trichoderma. 
Journal of Environmental toxicology. 1(3): 124-130.

Surendran, C., Sehgal, R. N. and Parmathma, M. 2003. Textbook of Forest Tree Breeding. Indian Council of Agricultural Research, New Delhi. Pp113.

Tak, A., and Jindal, S. K. 2014. Reproductive biology of Acacia Senegal (L.) Willd. International Journal of Advances in Research. 2(5): 498-502.

Tewari, J. C., Harsh, L. N., Sharma, N. K., Bohra, M. D., and Tripathi, D. 2012. Variation and interrelations among tree characters, pod-seed morphology and pod biochemical characters in Prosopis juliflora (sw) dc. Forests, Trees and Livelihoods. 11(2): 113-126.

Troup, R. S., 1921. Silviculture of Indian Trees, Clarendon Press. London, 3: 152.

Turnbull, J. W., 1975. Seed collection, sampling consideration and collection techniques In: Report of FAO/DANIDA training course of forest seed collection on handling held in Chiang Mai, Thailand, Feb/March, FAO/TF/RAS11(DEN), FAO, Rome.
Valentina, P., Ilango, K., Kiruthiga, B., and Parimala, M. J. 2013. Preliminary phytochemical analysis and biological screening of extract of leaves of Melia dubia CAV. International Journal of Research Ayurveda Pharm. 4(3): 417419.

Vargas-Reeve, F., Mora, F., Perret, S., and Scapim, C. A. 2013. Heritability of stem straightness and genetic correlations in Eucalyptus cladocalyx in the semi-arid region of Chile. Crop Breeding and Applied Biology. 13(2): 107-112.

Wani, N. R., Malik, T. H. 2014. Role of Poplars in Agroforestry Systems in India. New York Science Journal. 7(20): 50-56.

Yasodha, D., Manimegalai, M., Binu, K. S., and Vijayakumar, K. 2012. Larvicidal effect of Melia dubia seed extract against the malarial fever mosquito, Culex quinquefasciatus. Current Biotica. 5(1):102-106.

Zobel, B. J., and Talbert, J. 1984. Applied Tree Improvement. John Wiley \& Sons, Inc., New York.

\section{How to cite this article:}

Chauhan, R.S., D.B. Jadeja, N.S. Thakur, S.K. Jha and Sankanur, M.S. 2018. Selection of Candidate Plus Trees (CPTs) of Malabar Neem (Melia dubia Cav.) for Enhancement of Farm Productivity in South Gujarat. Int.J.Curr.Microbiol.App.Sci. 7(05): 3582-3592. doi: https://doi.org/10.20546/ijcmas.2018.705.414 